\title{
Türkiye'de Özel Sağlık Sigortaları ve Etkinlik Analizi
}

\section{Private Health Insurances and Their Efficiency Analysis in Turkey}

\section{Abdulaziz Gülay $^{1}$ (D) İClal Attila $^{2}$ iD}

\section{Ö Z}

Özel sağlık sigortalarının rolü ve yaygınlığı tüm Dünyada sürekli olarak gelişme göstermektedir. Özel sağlık sigortalarının böylesine yaygınlık göstermesi, sigorta şirketlerinin faaliyetlerinde etkinlik ve verimlilik durumlarını gündeme getirmiştir. Şirketler etkinlik ölçümü yaparak kaynaklarını ne kadar verimli kullanabildiklerini ve faaliyetlerini hangi düzeyde etkin yürüttüklerini tespit ve analiz edebilmektedir. Bu sayede, zayıf veya yetersiz kaldıkları alanlarda gerekli düzeltme ve iyileştirmeleri yaparak yoğun rekabetin hakim olduğu piyasa koşullarında daha başarılı şekilde faaliyet yürütebilmektedir. Bu çalışmada 2017, 2018 ve 2019 yıllarında faaliyet gösteren sigorta şirketlerinin hastalık/sağlık branşındaki etkinliklerini ölçmek ve değerlendirmek amaçlanmıştır. Bu doğrultuda, Veri Zarflama Analizi yöntemi kullanılarak bahsi geçen 3 yılın tamamında hastalık/sağlık branşında prim üretimi yapan 31 sigorta şirketinin sağlık sigortası etkinlik analizleri yapılmış ve akabinde etkin olmayan sigorta şirketleri için etkin şirketler baz alınarak referans grupları oluşturulmuştur. Araştırmada elde edilen bulgular doğrultusunda söz konusu şirketlerinin toplam etkinliğinin analizin yapıldığı 3 yıl içerisinde sürekli yükseliş seyri gösterdiği saptanmıştır. Analizden elde edilen bulgular ışığında, Türkiye'de özel sağlık sigortalarının etkinlik düzeylerini yükseltmeyi hedefleyen bazı öneri ve argümanlara yer verilmiştir.

Jel Siniflamasi: I13, C14.

Anahtar Kelimeler: Özel Sağlık Sigortası, Veri Zarflama Analizi, Etkinlik.

\section{A B S T R A C T}

The role and prevalence of private health insurance is constantly evolving all over the world. The prevalence of private health insurances has brought up the issues of efficiency and productivity of insurance companies' activities. By measuring efficiency, companies can determine and analyze how efficiently they can use their resources and how effectively they perform their activities. In this way, by making the essential corrections and improvements in areas where they are weak or insufficient, they can operate more successfully in market conditions where intense competition is dominant. In this study, it is aimed to measure and evaluate the activities of insurance companies operating in 2017, 2018 and 2019 in the health insurance branch. In this direction, health insurance efficiency analyzes of 31 insurance companies that produced premiums in the disease/health branch during all of the aforementioned 3 years were executed using the Data Envelopment Analysis method. Then reference groups were created for the inefficient insurance companies based on the efficient companies. In line with the findings obtained from the research, it was determined that the total efficiency of the companies in question showed a continuous upward trend during the 3 years. In the light of the findings acquired from the analysis, some suggestions and arguments aiming to increase the efficiency levels of private health insurances in Turkey are given.

Jel Classification: I13, C14.

Keywords: Private Health Insurance, Data Envelopment Analysis, Efficiency.

\section{DOI: 10.47934/tife.10.02.01}

*Bu çalışma, Marmara Üniversitesi Bankacılık ve Sigortacıllk Enstitüsü bünyesinde Abdulaziz Gülay tarafından kaleme alınan "Türkiye'de özel Sağlık sigortaları ve Etkinlik Analizi” başlıklı Doktora tezinden türetilmiştir.

1. Doktora Öğrencisi, Marmara Üniversitesi, Bankacılık ve Sigortacılık Enstitüsü, İstanbul. ORCID: 0000-0003-3519-002X

2. Prof Dr, Marmara Üniversitesi, Siyasal Bilgiler Fakültesi, Siyaset Bilimi ve Kamu Yönetimi Bölümü, İstanbul.

ORCID: 0000-0002-5584-8936

\section{SORUMlu Yazar / CoRresponding AUTHOR}

İclal Atilla,

Marmara Üniversitesi, Siyasal Bilgiler Fakültesi, Siyaset Bilimi ve Kamu Yönetimi Bölümü, Göztepe, İstanbul.

E-mail: iclalattila@marmara.edu.tr

$\begin{array}{ll}\text { BAŞVURU/SUBMITTED: } & 12.07 .2021 \\ \text { REVIZYON TALEBI/ } & \\ \text { REVISION REQUESTED: } & 27.07 .2021 \\ \text { SON REVIZYON/ } & \\ \text { LAST REVISION : } & - \\ \text { KABUL/ACCEPTED: } & 27.07 .2021\end{array}$

Atıf / Citation: Gülay, A., Attila, İ. (2021). Türkiye'de Özel Sağlık Sigortaları ve Etkinlik Analizi. Trakya Üniversitesi İktisadi ve İdari Bilimler Fakültesi e-Dergi, 10(2), 68-85, https://doi.org/10.47934/tife.10.02.01 


\section{Giriş}

Türkiye' de ağırlıklı kamusal sağlık sigortası mekanizması olarak sosyal sigorta prensibine dayanan Genel Sağlık Sigortası sistemi tatbik edilmektedir. Genel Sağlık Sigortasına destekleyici ve tamamlayıcı fonksiyonda özel sağlık sigortaları faaliyet göstermektedir. Özel sağlık sigortacılığı özellikle ülkemizde her geçen yıl büyüyen ve gelişen bir sektör olarak dikkati çekmektedir. Sürekli yükselen sağlık harcamaları, toplumun sağlık konusunda bilinç ve farkındalığının artması ve bireylerin daha lüks ve kaliteli sağlık hizmeti alma arzusu özel sağlık sigortalarına olan eğilimi arttırmaktadır.

Tüm dünyada olduğu gibi ülkemizde de özel sağlık sigortalarının rolü ve yaygınlığı sürekli olarak gelişme göstermektedir. Türkiye'de 2012 yılında özel sağlık sigortası yaptıran kişi sayısı yaklaşık 5,4 milyon iken, 2019 yılında bu sayı 7,2 milyona yükselmiştir (T.C. Hazine ve Maliye Bakanlığı Sigorta Denetleme Kurulu, 2020). Benzer şekilde, hastalık/sağlık branşında 2010 yılında brüt prim üretimi yaklaşık 1,67 milyar Lira iken, 2019 yılında bu miktar neredeyse 5 katına çıkarak 8,05 milyar TL'ye ulaşmıştır (Türkiye Sigorta Birliği, 2020). Özel sağlık sigortalarının böylesine yaygınlık göstermesi, sigorta şirketlerinin faaliyetlerinde etkinlik ve verimlilik durumlarını gündeme getirmiştir.

Bu çalışmada Türkiye'de faaliyet gösteren özel sağlık sigortalarının 2017, 2018 ve 2019 yıllarına ilişkin etkinlik analizi yapılmıştır. Bu analiz neticesinde, özel sağlık sigortalarının etkinlik düzeylerini arttırabilecek öneriler ileri sürmek amaçlanmıştır. Bu doğrultuda, sigorta şirketlerinin hastalık-sağlık branşındaki çeşitli finansal verileri girdi ve çıktı parametreleri olarak kullanılarak Veri Zarflama Analizi yöntemiyle bir finansal etkinlik analizi gerçekleştirilmiştir.

\section{2. Özel Sağlık Sigortası: Tanım ve Kavram}

Özel sağlık sigortası; hastalık veya kaza risklerinin meydana gelmesi sonucu, bireylerin eski sağlıklarına kavuşmak amacıyla yararlandıkları sağlık hizmetlerinin masraflarını poliçede kararlaştırılan belirli limitler doğrultusunda, genel veya özel şartlar çerçevesinde karşılayan bir özel sigorta türüdür (OECD, 2019, s.1). Bireylerin sigortalanabilmesi için herhangi bir sosyal güvenlik sistemine kayıtlı olup olmadıkları dikkate alınmamaktadır. Katılım (bazı ülkelerde istisnaları olmakla birlikte) isteğe bağlıdır (Çelik, 2016, s.182). Öncesinde prim ödemek koşuluyla, sigortalıların sağlık hizmet sunucularından almış olduğu ve poliçede belirtilen teşhis, tetkik, muayene, ayakta veya yatarak tedavi ve ilaç gibi sağlık hizmetlerinin bedelleri kısmen veya tamamen özel sağlık sigortası şirketi tarafından karşılanmaktadır (Orhaner, 2006, s.9).

Özel sağlık sigortaları hemen hemen tüm ülkelerde uygulanmakla birlikte, çoğunlukla mevcut kamu sağlık sigortasının eksik veya yetersiz kaldığı alanlarda tamamlayıcı rolde tatbik edilmektedir. Kişiler daha lüks ve konforlu sağlık hizmeti almak ve talep ettikleri sağlık hizmetlerinin teminat kapsamını genişletmek gibi amaçlarla özel sağlık sigortalarını tercih etmektedir (Claxton, 2002, ss.1-2). Özellikle kişi başı gelirin yüksek olduğu, güçlü ekonomisi olan gelişmiş ülkelerde yaygın olarak uygulanan bir finansman yöntemidir (Gottret ve Schiber, 2006, s.5). Gelişmekte olan ülkelerde özel sağlık sigortalarına olan talep her geçen gün artış göstermektedir. Bu durumun en temel sebepleri; vatandaşların kamu sağlık sigortası sisteminden memnuniyetsizlikler duyması, ülkelerdeki ekonomik büyümeler, tüketicilerin daha kaliteli ve yüksek standartlarda sağlık hizmeti arzulaması ve toplumdaki sağlık bilinci ve farkındalığının sürekli gelişmesidir (Drechsler ve Jütting, 2005, s.4).

\section{3. Özel Sağıık Sigortası Türleri}

Birçok ülkede yaygın şekilde uygulanan bir finansman sistemi olan özel sağlık sigortaları literatürde çeşitli şekillerde sınıflandırılmıştır. OECD’nin 2004 yılında yayınladığı "Sağlık Sigortası İçin Bir Sınıflandırma Önerisi" başlıklı çalışmada özel sağlık sigortaları ikame edici, destekleyici ve tamamlayıcı sigortalar olmak üzere 3 grup olarak sınıflandırılmıştır (OECD, 2004, s.18). 


\section{1. İkame Edici Özel Sağlık Sigortası}

İkame edici özel sağlık sigortası, devletin sağlamış olduğu kamu sağlık sigortasının yerine uygulanan ve sunduğu temel teminat paketleri kapsamında sağlık risklerini teminat altına alan bir özel sağlık sigortası türüdür(Orhaner ve Ekinci, 2019, s.34). Dolayısıyla ikame edici sigortalar, sosyal sağlık sigortasının yerine geçmekte ve teminat paketleriyle söz konusu sağıık risklerini üstlenmektedir. Çoğunlukla kamu sağlık sigortası kapsamının dışında kalan veya kendi isteğiyle kamusal sigorta kapsamından ayrılan bireyler için uygulanmaktadır (Doğukan, 2014, s.4).

\subsection{Destekleyici Özel Sağlık Sigortası}

Destekleyici özel sağlık sigortası, kamu sağlık sigortasının karşılamadığı ek sağlık hizmetlerini teminat kapsamına alan özel sağlık sigortası türüdür. Bu sigortalarla tüketicinin seçme şansını arttırmak, sağlık hizmetlerine daha hızlı erişimi sağlamak ve lüks otelcilik hizmetlerinin bedellerini karşılamak amaçlanmaktadır. Genellikle, maliyeti kamunun sunduğu sağlık sigortasıyla aynı olan sağlık hizmetlerinde uygulanmaktadır. Özellikle sağlık hizmet sunucularında bekleme sürelerini kısaltması sebebiyle tercih edilmektedir. İspanya, Yunanistan ve İtalya başta olmak üzere birçok Avrupa ülkesinde uygulanmaktadır (Paolucci, Schut, Beck ve Greb, 2007, ss.173-174). Destekleyici sağlık sigortalarında temel amaç; sağlık ve bakım hizmetlerinde kaliteyi arttırmaktan ziyade, sigortalıların tercih imkanını genişletmek ve lüks otelcilik hizmetlerine ulaşımını kolaylaştırmaktır (Mossialos ve Thomson, 2004, s.35).

\subsection{Tamamlayıcı Özel Sağlık Sigortası}

Tamamlayıcı özel sağlık sigortası; kamu sağlık sigortası tarafından teminat kapsamına alınmayan veya teminat kapsamına alındığı halde ek ücret ödenmesini gerektiren sağlık hizmetlerinin giderlerini belirli şartlar ve limitler çerçevesinde karşılayan bir özel sağlık sigortası türüdür (Erkek ve Erkek, 2012, s.35). Diğer bir deyişle, kamu sağlık sigortasının kısmen veya tamamen karşılamadığı sağlık hizmetlerinde kişinin ödemesi gereken ilave ücret tutarları tamamlayıcı sigortalar aracılığıyla finanse edilmektedir (Tajika ve Kikuchi, 2012, s.129).

Tamamlayıcı sağlık sigortaları ABD, Hollanda ve Almanya başta olmak üzere, dünya genelinde birçok ülkede yaygın olarak uygulanmaktadır. Avrupa'nın birçok ülkesinde özel sağlık sigortaları ağırlıklı olarak tamamlayıcı sağlık sigortası şeklinde tatbik edilmekte ve kamu sağlık sigortasının karşılamadığı sağlık hizmetlerinin giderlerini teminat altına almaktadır (Lister, 2008, s.113). Türkiye'de ise tamamlayıcı sağılı sigortalarına dair ilk yasal düzenleme SGK'nın 28 Haziran 2012'de yayınladığı 2012/25 sayılı genelgedir. Bu düzenleme ile özel sağlık hizmet sunucularında SGK'nın ödediği meblağın üzerinde kalan ek maliyetlerin tamamlayıcı sigorta kapsamında finanse edilebilmesi mümkün hale gelmiştir. Böylece SGK'nın ödeme limitinin üstünde kalan bedeller, tamamlayıcı sağlık sigortası kapsamında sigortalı adına anlaşmalı sağlık hizmet sunucularına ödenmektedir. Bu şekilde tamamlayıcı sigorta sahipleri, bu bedeller için provizyon esnasında cepten ödeme yapmak zorunda kalmamaktadır (Özer, Gözlü, Karsavuran ve Gözlü, 2014, ss.10-11).

\section{Türkiye'de Özel Sağlık Sigortacılı̆̆ı}

Türkiye'de sağlık harcamalarının finansmanında Bismarck Modelinin ağırlıkta olduğu ve tüm nüfusu kapsayan Genel Sağıık Sigortası uygulanmaktadır. GSS kapsamında yer almak Kanun gereği her Türkiye Cumhuriyeti vatandaşı için zorunludur. Gelir sahibi her birey GSS'ye prim ödemekle yükümlüdür (Özbolat, 2014, s.72). Özel sağlık sigortası yaptıran vatandaşların Genel Sağlık Sigortası kapsamından çıkma seçeneği veya hakkı bulunmamaktadır. Bu kişiler kamu sağlık hizmet sunucularını kullanmasalar bile Genel Sağıık Sigortası kapsamında SGK'ya prim ödemek zorundadır. Bu durum Türkiye'de özel sağlık sigortası 
almanın maliyetini yükseltmektedir. Ayrıca GSS kapsamından çıkmanın kanunen mümkün olmaması, özel sağlık sigortalarına katılımı azaltmaktadır (Su, 2004, s.1).

Ülkemizde özel sağlık sigortaları bir dönem kaza sigortası kapsamında satılırken 1990 yılından itibaren hastalık sigortası adıyla ayrı bir sigorta branşı yapılmıştır. Özel sağlık sigortalarında mevcut durumda serbest tarife rejimi uygulanmaktadır. Teminat kapsamı ve prim tutarları, serbest piyasa şartlarına göre sigorta şirketleri tarafından belirlenmektedir (Civan, 2010, s.88). Sağlık Sigortası Genel Şartları, özel sağlık sigortalarının hukuki çerçevesini oluşturmaktadır. Sigorta şirketleri hazırladıkları poliçelerde genel şartlara aykırı hüküm koyamamaktadır. Bununla birlikte, genel şartlara aykırı olmamak kaydıyla poliçelere özel şartlar eklenebilmektedir (Kaya ve Kahya, 2017, s.28).

Özel sağlık sigortası poliçeleri bireysel olarak ya da aile üyeleri de dahil olacak şekilde paket olarak satın alınabilmektedir. Ayrıca, işverenler isteğe bağı olarak çalışanlarını ve çalışanlarının aile fertlerini sigortalatabilmektedir. Hukuken zorunlu olduğundan dolayı GSS'ye prim ödeyen özel sağlık sigortası sahipleri, söz konusu özel sağlık sigortası için de ayrıca prim ödemesi yapmaktadır. Bu sebeple özel sağlık sigortası yaptıran kişiler, kamu sağlık hizmet sunucularına hiç başvurmasa dahi hem SGK'ya hem de özel sigorta şirketine ayrı ayrı prim ödemesi yapmaktadır (Bölükbaşı ve Pamukçu, 2008, s.34).

\section{Veri Zarflama Analizi Yöntemiyle Türkiye’deki Özel Sağlık Sigortalarının Etkinlik Analizi}

Çalışmada sigorta şirketlerinin bahsi geçen yıllardaki hastalık/sağlık branşı etkinliklerini ölçmek amacıyla Veri Zarflama Analizi kullanılmıştır. VZA'da birbiriyle ilişkili tüm girdi çıktı parametreleri, veri setine dahil edilebilmekte ve herhangi bir veriyi dışarıda bırakmak zorunda kalmadan etkinlik skoru sorunsuz şekilde hesaplanabilmektedir.

Analiz neticesinde etkinlik skoru 1'e eşit olan KVB'ler, göreli olarak etkin olan şirketlerdir. Etkinlik değer 0 ile 1 arasında çıkan şirketler ise etkin olmayan şirketleri ifade etmektedir. Analiz için Microsoft Windows İşletim Sistemi üzerinde çalıştırılabilen ve kullanımı oldukça kolay olan Win4Deap2 paket programı kullanılmıştır. Etkinlik ölçümü için çıktıya yönelik CCR modeli tercih edilmiştir

\subsection{Literatür Taraması}

Mirmirani ve Lippman (2003), Veri Zarflama Analizinin CCR ve BCC modellerini uygulayarak yaptıkları çalışmada G12 ülkelerinin 1991, 1993 ve 1995 yıllarında sağlık sistemleri etkinlik durumlarını analiz etmiştir. Analizde girdi olarak kişi başı ortalama sağılı harcaması, hastane yatak sayısı, MRI sayısı ve hekim başına düşen nüfus verileri kullanıımıştır. Doğumda beklenen yaşam süresi ile bebek ölüm oranı analizin çıktılarını oluşturmuştur. Analiz sonucunda, etkinlik sıralamasında i̇spanya birinci çıkarken Japonya en etkin ikinci ülke olmuştur. ABD entkinlik düzeyi en düşük ülke olarak son sırada yer almıştır.

Afonso ve Aubyn (2007), Veri Zarflama Analizi uygulayarak 21 OECD ülkesinin sağlık sistemlerinin verimliliğini analiz etmiştir. Çalışmada girdi olarak hekim sayısı, MRI sayısı, hemşire sayısı ve hastane yatak sayısı kullanılmıştır. Doğumda beklenen yaşam süresi, sağlıklı yaşam süresi ve bebek ölüm oranı verileri ise çıktı değişkenleri olarak seçilmiştir. Ölçeğe göre değişken getiri, yani VRS modelinin tercih edildiği analizin sonuçlarına göre ülkelerin 7 tanesinin sağlık sistemleri $(\% 33,3)$ verimli çıkmıştır. Bu ülkeler; Japonya, ABD, İsveç, Güney Kore, Kanada, İspanya ve Finlandiya'dır. Çalışmada, sağlık sistemlerindeki verimsizliğin kişi başı milli gelir, eğitim düzeyi, obezite ve sigara içme alışkanlıklarıyla yakından ilişki içinde olduğu tespit edilmiştir.

Kayalı (2007) “2000 - 2006 Döneminde Türkiye' de Faaliyet Gösteren Sigorta Şirketlerinin Etkinlik Değerlendirmesi” başlıklı makalesinde 2000 ile 2006 yılları arasında Türkiye'de faaliyet yürüten sigorta şirketlerinin teknik ve ölçek etkinliklerini araştırmıştır. Çalışmada etkinlik ölçüm yöntemi olarak Veri Zarflama Analizi kullanılmıştır. Şirketlerin dönemler arasındaki etkinlik değerlerinin değişimi Malmquist 
Toplam Faktör Verimlilik Endeksi Kullanılarak ölçülmüştür. Analizin bulgularında 2000ile 2006 yılları arasında Türkiye'deki sigorta şirketlerinin etkinlik değerlerinde doğrusal artış olduğu tespit edilmiştir

Lorcu (2008), Veri Zarflama Analizi kullanarak hazırlamış olduğu doktora tezinde, AB üyesi 27 ülke ve aday ülke olarak Türkiye'nin sağılık sistemlerindeki mevcut etkinlik performanslarını analiz etmiştir. Ölçeğe göre sabit getiri (CCR) modelinde yapılan analizin sonuçlarına göre; Türkiye'nin de aralarında bulunduğu 11 ülke etkin, 17 ülke ise etkinsiz çıkmıştır. Ölçeğe göre değişken getiri (VRS) modelindeyse Türkiye dahil 13 ülke etkin çıkarken, 15 ülke etkin değildir. Avusturya, 0,684 ile etkinlik skoru en düşük ülke olmuştur.

Mirmirani (2008), Veri Zarflama Analizi yöntemini kullanarak geçiş ekonomisine sahip ülkelerin sağlık sistemlerinin etkinliklerini ölçmüştür. Bu doğrultuda 1997 ile 2001 arası bir yılın verileri ayrı ayrı analiz edilmiştir. Çalışmada girdi olarak kızamık vakası sayısı, hekim sayısı, toplam sağlık harcaması ve hastane yatak sayısı parametreleri kullanılırken; çıktı olarak bebek ölüm oranı ve ortalama yaşam süresi değişkenlerine yer verilmiştir. Analiz sonuçlarına göre, 5 yılın tamamında Arnavutluk etkinlik düzeyi en yüksek ülke olurken, Rusya 0,864 etkinlik puanıyla son sırada yer almıştır.

Kılınç (2009), yayınlanmış yüksek lisans tezinde Veri Zarflama Analizi uygulayarak Türkiye'deki sigorta şirketlerinin etkinlik düzeylerini araştırmıştır. Çalışmada 2008 yılında hayat, hayat dışı ve emeklilik sigortası branşlarında faaliyet gösteren 37 sigorta şirketinin etkinlikleri ölçülmüştür. Araştırmanın bulgularına göre, 31 sigorta şirketlerinin etkin durumda olduğu saptanmış ve etkin olmayan şirketlerin yönetsel kararlarında girdi ve çıktı bileşenlerini gözden geçirmeleri tavsiye edilmiştir.

Yıldız (2012), “Özel Sağlık Sigortacılığı Sektöründe Faaliyet Gösteren Şirketlerin Veri Zarflama Analizi İle Etkinliğinin Ölçülmesi" başlıklı yüksek lisans tezinde, Veri Zarflama Analizi yöntemini kullanarak Türkiye' de sağlık sigortacılığı sektöründe faaliyet gösteren sigorta şirketlerinin etkinlik analizini yapmıştır. Çıktıya yönelik VZA yönteminin uygulandığı çalışmada veriler DEAP V. 2.1 paket programında analiz edilmiştir. Karar verme birimleri olarak, 2011 yılında Türkiye'de özel sağlık sigortası hizmeti sunan 27 sigorta şirketi seçilmiştir. Çalışmada girdi olarak; personel sayısı, acente sayısı, duran varlıklar, dönen varlıklar, aktifler toplamı ve özkaynaklar kullanılmıştır. Çıktılar ise toplam prim üretimleri, teknik kar ve mali kardır. Çalışmanın sonuçlarına göre CCR modelinde 8 şirket, BCC modelindeyse 13 şirket etkin olarak tespit edilmiştir.

Asandului, Roman ve Fatulescu (2014), "Theefficiency of HealthCareSystems in Europe: A Data Envelopment Analysis Approach" başlıklı makalede, Veri Zarflama Analizi uygulayarak 30 Avrupa ülkesinin sağlık sistemlerinin etkinliğini araştırmıştır. Analizde girdi değişkenleri olarak hekim sayısı, sağlık tesisi yatak sayısı ve gayrisafi yurtiçi hasıladan sağlığa ayrılan paylar kullanılmıştır. Çıktı değişkenleri ise sağlıklı yaşam beklentisi, doğumda beklenen yaşam süresi ve bebek ölüm oranlarıdır. Analiz sonucunda, ölçeğe göre sabit getiri (CRS) modelinde verimlilik ortalaması 0,74 olmuş ve 30 ülkeden sadece 5 tanesi etkin çıkmıştır. Bunlar; İngiltere, İsveç, Romanya, Kıbrıs ve Bulgaristan'dır.

Medeiros ve Schwierz (2015), Veri Zarflama ve Kümeleme Analizi yöntemlerini kullanarak tüm Avrupa ülkelerinin sağık sistemlerindeki etkinlik durumlarını ölçmüş ve değerlendirmiştir. Araştırma sonucunda Çek Cumhuriyeti, Slovakya ve Litvanya verimlilik düzeyi en düşük olan ülkeler çıkmıştır. Fransa, İspanya, Belçika, Hollanda ve İtalya ise verimlilik seviyeleri yüksek çıkan ülkeler arasında yer almıştır.

\subsection{Karar Verme Birimlerinin Seçimi (Gözlem Kümesinin Belirlenmesi)}

Karar verme birimleri; göreli etkinlikleri analiz edilen banka, sigorta şirketi, okul veya hastane gibi ekonomik faaliyet yürüten çeşitli işletme, firma, kurum ve organizasyonları ifade etmektedir. Söz konusu karar verme birimleri, faaliyet yöntemleri ve üretim teknolojileri bakımından birbirlerine benzer olmalıdır. Çünkü göreli etkinliğin ölçülebilmesi ve etkinlik düzeylerinin karşılaştırılabilmesi için, birbirine yakın üretim 
alanlarında faaliyet yürüten ve aynı işletmecilik kararlarının uygulandığı türdeş ve homojen KVB'lerin mukayese edilmesi gerekmektedir(Yolalan, 1993, s.37).

Bu çalışmada 4 girdi ve 2 çıktı değişkeni kullanılarak 31 karar verme biriminin etkinliği ölçülmüştür. Çalışmanın KVB'leri, Türkiye'de faaliyet gösteren ve 2016, 2017, 2018 ve 2019 yıllarının tamamında hastalık/sağlık branşında prim üretimi gerçekleştirmiş 31 sigorta şirketidir

Tablo 1. Çalışmada Etkinlikleri Analiz Edilen Karar Verme Birimleri

\begin{tabular}{cccc}
\hline Şirket Kodu & ŞirketAdı & Şirket Kodu & ŞirketAdı \\
\hline KVB 1 & Aksigorta & KVB 17 & Gulf \\
\hline KVB 2 & Allianz & KVB 18 & Güneş Sigorta \\
\hline KVB 3 & Anadolu Sigorta & KVB 19 & Halk Sigorta \\
\hline KVB 4 & Ankara Sigorta & KVB 20 & HDI \\
\hline KVB 5 & Axa & KVB 21 & Mapfre \\
\hline KVB 6 & Bereket (Işı) & KVB 22 & Mapfre Yaşam \\
\hline KVB 7 & Bupa Acıbadem & KVB 23 & Neova \\
\hline KVB 8 & Chubb (ACE) & KVB 24 & Orient \\
\hline KVB 9 & Corpus (Turkland) & KVB 25 & Ray Sigorta \\
\hline KVB 10 & Demir Hayat & KVB 26 & Şeker Sigorta (SBN) \\
\hline KVB 11 & Doğa Sigorta & KVB 27 & Sompo Japan \\
\hline KVB 12 & Dubai Starr & KVB 28 & Türk Nippon \\
\hline KVB 13 & Ethica & KVB 29 & Unico \\
\hline KVB 14 & Eureko & KVB 30 & Ziraat \\
\hline KVB 15 & Generali & KVB 31 & Zurich \\
\hline KVB 16 & Groupama & & \\
\hline
\end{tabular}

\subsection{Girdi ve Çıktı Değişkenlerinin Belirlenmesi}

Bir etkinlik ölçüm yöntemi olarak Veri Zarflama Analizi, kullanılan girdi ve çıktı bileşiminin seçimine ve veri hatalarına karşı oldukça duyarlı ve hassastır. Bu sebeple, analizde kullanılacak girdi ve çıktı değişkenlerinin belirlenmesi sürecinde son derece titiz ve dikkatli hareket etmek gerekmektedir. Buna ek olarak, seçilen girdi ve çıktılar birbiriyle ilişkili ve türdeş olmalıdır. Sadece nedensel olarak birbirleriyle bağlantılı olan girdi ve çıktılar veri setine dahil edilmelidir. Girdi-çıktı değişkenlerinin homojen ve benzer yapıda olması, etkinlik skorlarını ve analizin anlamlı sonuçlar vermesini doğrudan etkilemektedir (Kılıçkaplan ve Karpat, 2004, s.7).

Bahsi geçen bilgiler ışığında ve literatürde yaygın kabul gören bilimsel yaklaşımlara paralel olarak; bu çalışmada 2017, 2018 ve 2019 yıllarında Türkiye'de hastalık/sağlık branşında prim üretimi yapmış 31 sigorta şirketinin personel sayısı, bankalar hariç acente sayısı, duran varlıklar ve toplam özsermaye verileri girdi parametreleri olarak kullanılmıştır. Prim üretimleri ve teknik kar verileri ise çalışmanın çıktı değişkenlerini oluşturmaktadır. Söz konusu 31 sigorta şirketine ait tüm girdi ve çıktı verileri, T.C. Hazine ve Maliye Bakanlığı Sigorta Denetleme Kurulu tarafından periyodik olarak yayınlanan 2018, 2019 ve 2020 tarihli 'Sigortacılık ve Bireysel Emeklilik Faaliyetleri Hakkında Rapor' başlıklı yıllık raporlardan temin edilmiş ve derlenmiştir. 
Tablo 2. Analizde Kullanılan Girdi ve Çıktı Değişkenleri

\section{GirdiDeğişkenleri}

Personel Sayısı

Acente Sayısı (Bankalar Hariç)

Duran Varlıklar

Toplam Özkaynaklar

\section{ÇıktıDeğişkenleri}

Sağlık/Hastalık Branşı Prim Üretimleri

Sağlık/Hastalık Branşı Teknik Kar

\subsection{Bulgular}

Çalışmanın bu bölümünde söz konusu 31 sigorta şirketinin 2017, 2018 ve 2019 yıllarında hastalık/sağlık branşındaki etkinlikleri analiz edilmiştir. Bu doğrultuda, Veri Zarflama Analizi'nin çıktı yönlü CCR modeli uygulanarak etkinlik skorları tespit edilmiş ve bulgular paylaşılmıştır.

\subsubsection{Yılı Analiz Sonuçları}

Tablo 3. 2017 Yılı Etkinlik Skorları ve Referans Grupları

\begin{tabular}{|c|c|c|c|}
\hline ŞirketAdı & $\begin{array}{l}2017 \\
\text { EtkinlikSkoru }\end{array}$ & $\begin{array}{c}\text { ReferansGrupları (Benchmarks) ve Lambda } \\
\text { Ağırlıkları (\%) }\end{array}$ & ReferansOlmaSayısı \\
\hline Aksigorta & 0,241 & $\begin{array}{c}\text { Corpus }(3,52) \text {, Bupa Acıbadem }(1,18) \text {, Chubb } \\
(3,54)\end{array}$ & 0 \\
\hline Allianz & 0,625 & Bupa Acıbadem $(3,11)$, Chubb $(9,39)$ & 0 \\
\hline $\begin{array}{l}\text { Anadolu } \\
\text { Sigorta }\end{array}$ & 0,148 & Bupa Acıbadem $(4,02)$ & 0 \\
\hline $\begin{array}{l}\text { Ankara } \\
\text { Sigorta }\end{array}$ & 0,756 & $\begin{array}{l}\text { Corpus }(0,56) \text {, Bupa Acıbadem }(0,03) \text {, Chubb } \\
\qquad(1,80)\end{array}$ & 0 \\
\hline Axa & 0,228 & $\begin{array}{l}\text { Chubb }(8,99) \text {, Corpus }(0,09) \text {, Bupa Acıbadem } \\
\qquad(1,007)\end{array}$ & 0 \\
\hline Bereket & 0,333 & $\begin{array}{l}\text { Chubb (1,04), Corpus (1,95), Bupa Acıbadem } \\
\qquad(0,005)\end{array}$ & 0 \\
\hline $\begin{array}{l}\text { Bupa } \\
\text { Acıbadem }\end{array}$ & 1 & Bupa Acıbadem $(1,00)$ & 20 \\
\hline Chubb & 1 & Chubb $(1,00)$ & 22 \\
\hline Corpus & 1 & Corpus $(1,00)$ & 20 \\
\hline $\begin{array}{l}\text { Demir } \\
\text { Hayat }\end{array}$ & 1 & Demir Hayat $(1,00)$ & 6 \\
\hline $\begin{array}{l}\text { Doğa } \\
\text { Sigorta }\end{array}$ & 0,223 & $\begin{array}{l}\text { Chubb (1,82), Corpus (2,65), Bupa Acıbadem } \\
\qquad(0,12)\end{array}$ & 0 \\
\hline Dubai Starr & 0,766 & Demir Hayat $(0,67)$, Corpus $(0,54)$, Chubb $(0,33)$ & 0 \\
\hline Ethica & 0,751 & $\begin{array}{l}\text { Chubb (1,24), Corpus }(0,14) \text {, Bupa Acıbadem } \\
\qquad(0,004)\end{array}$ & 0 \\
\hline Eureko & 0,094 & Ziraat $(0,39)$, Bupa Acıbadem $(1,48)$ & 0 \\
\hline Generali & 0,311 & Demir Hayat $(0,95)$, Corpus $(1,73)$, Chubb $(0,97)$ & 0 \\
\hline
\end{tabular}




\begin{tabular}{|c|c|c|c|}
\hline Groupama & 0,249 & $\begin{array}{c}\text { Chubb (1,31), Corpus }(3,59) \text {, Bupa Acıbadem } \\
\qquad(0,63)\end{array}$ & 0 \\
\hline Gulf & 0,393 & Demir Hayat $(1,75)$, Corpus $(0,41)$, Chubb $(1,90)$ & 0 \\
\hline $\begin{array}{l}\text { Güneş } \\
\text { Sigorta }\end{array}$ & 0,081 & Bupa Acıbadem $(1,96)$ & 0 \\
\hline $\begin{array}{l}\text { Halk } \\
\text { Sigorta }\end{array}$ & 0,289 & Demir Hayat $(0,29)$, Corpus $(1,85)$, & 0 \\
\hline HDI & 0,173 & Bupa Acıbadem $(0,12)$, Chubb $(2,56)$ & 0 \\
\hline Mapfre & 0,204 & $\begin{array}{l}\text { Corpus }(1,98) \text {, Bupa Acıbadem }(0,07) \text {, Chubb } \\
\qquad(4,90)\end{array}$ & 0 \\
\hline $\begin{array}{l}\text { Mapfre } \\
\text { Yaşam }\end{array}$ & 0,838 & Bupa Acıbadem $(2,95)$ & 0 \\
\hline Neova & 0,204 & Chubb $(0,16)$, Corpus $(0,81)$, Demir Hayat $(0,32)$ & 0 \\
\hline Orient & 0,598 & Chubb $(3,93)$, Corpus $(1,14)$ & 0 \\
\hline Ray Sigorta & 0,185 & Chubb $(0,15)$, Corpus $(1,52)$ & 0 \\
\hline $\begin{array}{l}\text { Şeker } \\
\text { Sigorta }\end{array}$ & 0,685 & $\begin{array}{l}\text { Chubb }(1,88) \text {, Corpus }(3,11) \text {, Bupa Acibadem } \\
\qquad(0,12)\end{array}$ & 0 \\
\hline $\begin{array}{l}\text { Sompo } \\
\text { Japan }\end{array}$ & 0,225 & $\begin{array}{l}\text { Corpus }(0,69) \text {, Bupa Acıbadem }(0,02) \text {, Chubb } \\
\qquad(0,73)\end{array}$ & 0 \\
\hline $\begin{array}{l}\text { Türk } \\
\text { Nippon }\end{array}$ & 0,739 & $\begin{array}{l}\text { Corpus }(1,05) \text {, Bupa Acıbadem }(0,30) \text {, Chubb } \\
\qquad(9,60)\end{array}$ & 0 \\
\hline Unico & 0,307 & $\begin{array}{l}\text { Corpus }(0,93) \text {, Bupa Acıbadem }(0,04) \text {, Chubb } \\
\qquad(0,75)\end{array}$ & 0 \\
\hline Ziraat & 1 & $\begin{array}{l}\text { Chubb }(0,86) \text {, Corpus }(2,90) \text {, Bupa Acıbadem } \\
\qquad(0,02)\end{array}$ & 1 \\
\hline Zurich & 0,308 & Ziraat $(1,00)$ & 0 \\
\hline ORTALAMA & 0,482 & & \\
\hline
\end{tabular}

Tablo 3'te görüldüğü gibi Bupa Acıbadem, Demir Hayat, Chubb, Corpus ve Ziraat 2017 yılının etkin şirketleri olarak göze çarpmaktadır. Etkin şirket sayısı 5'te kalmıştır. Güneş sigorta 0,081 ve Eureko 0,094 skorlarıyla etkinliği en düşük şirketler olarak öne çıkmaktadır. Etkin olmayan birimler arasında Mapfre Yaşam $(0,838)$ ile Dubai Starr $(0,766)$ ise etkin olmaya en çok yaklaşan şirketler olmuştur. 31 şirketin 2017 yılı genel etkinlik ortalaması 0,482 olmuş ve 2016'ya göre az da olsa artış göstermiştir.

Etkin olan şirketlerden Chubb 22, Bupa Acıbadem ile Corpus ise 20 defa başvuru grubunda referans gösterilmiştir. Bu şirketleri 6 kez referans olan Demir Hayat ve 1 kez referans olan Ziraat takip etmiştir. Etkin olmayan şirketler için hangi oranlarda hangi şirketleri referans alacağı da başvuru grubunda ayrıntılı olarak sunulmuştur. Örneğin etkinlik skoru en düşük şirketlerden biri olan Eureko'nun etkin hale gelebilmesi için Ziraat'i \%39 ve Bupa Acıbadem'i \%148 oranında referans (örnek) alması gerekmektedir. Etkin olmayan şirketler arasında etkinlik skoru en yüksek olan $(0,838)$ Mapfre Yaşam'ın etkin olması için ise Chubb'ı \%16, Corpus'u \%81 ve Demir Hayat'ı \%32 oranında referans alması gereklidir.

Etkin olan şirketlerden Chubb 22, Bupa Acıbadem ile Corpus ise 20 defa başvuru grubunda referans gösterilmiştir. Bu şirketleri 6 kez referans olan Demir Hayat ve 1 kez referans olan Ziraat takip etmiştir. Etkin olmayan şirketler için hangi oranlarda hangi şirketleri referans alacağı da başvuru grubunda ayrıntılı olarak sunulmuştur. Örneğin etkinlik skoru en düşük şirketlerden biri olan Eureko'nun etkin hale gelebilmesi için Ziraat' $i$ \%39 ve Bupa Acıbadem'i \%148 oranında referans (örnek) alması gerekmektedir. Etkin olmayan şirketler arasında etkinlik skoru en yüksek olan $(0,838)$ Mapfre Yaşam'ın etkin olması için ise Chubb'ı \%16, Corpus'u \%81 ve Demir Hayat'ı \%32 oranında referans alması gereklidir. 


\subsubsection{Yılı Analiz Sonuçları}

Tablo 4'te şirketlerin 2018 yılı etkinlik skorları, referans grupları, referans olma ağırlıkları ve etkin şirketlerin referans olma sayıları verilmiştir. Buna göre, 2017 yılında etkin olan Bupa Acıbadem, Demir Hayat, Chubb, Corpus ve Ziraat; 2018 'de de etkinlik skoruna ulaşmıştır. Unico ise ilk defa bu yıl etkin şirketler arasına katılmıştır. 2016'da 0,375 ve 2017'de 0,482 olan genel etkinlik ortalaması 2018 yılında 0,520 olarak gerçekleşmiş ve 3 yıl içindeki sürekli yükselişini sürdürmüştür. Ayrıca analizin yapıldığı ilk 2 yılda etkin şirket sayısı 5 iken 2018 yılında etkin olan şirket sayısı 6'ya çıkmıştır. Bu sonuçlar 2017'den 2018'e sigorta şirketlerinin sağlık/hastalık branşında etkinlik düzeylerinin genel olarak yükseliş gösterdiğine işaret etmektedir.

Eureko 0,088 etkinlik skoruyla bu yıl da en düşük etkinlik düzeyine sahip şirket olmuştur. Eureko'nun ardından Güneş Sigorta $(0,105)$ ve Ray Sigorta $(0,109)$ en az etkin olan ikinci ve üçüncü şirketlerdir. Etkin olmayan şirketler arasında ise Dubai Starr 0,966 ve Mapfre Yaşam 0,908 etkinlik skorlarıyla etkin olmaya en çok yaklaşan şirketlerdir.

Tablo 4. 2018 Yılı Etkinlik Skorları ve Referans Grupları

\begin{tabular}{|c|c|c|c|}
\hline ŞirketAdı & $\begin{array}{l}2018 \\
\text { EtkinlikSkoru }\end{array}$ & $\begin{array}{c}\text { ReferansGrupları (Benchmarks) ve Lambda } \\
\text { Ağırlıkları (\%) }\end{array}$ & ReferansOImaSayısı \\
\hline Aksigorta & 0,256 & $\begin{array}{c}\text { Corpus }(7,55) \text {, Bupa Acıbadem }(0,94) \text {, Chubb } \\
(0,58)\end{array}$ & 0 \\
\hline Allianz & 0,652 & Chubb $(5,01)$, Corpus $(9,21)$,Bupa Acıbadem $(2,96)$ & 0 \\
\hline $\begin{array}{l}\text { Anadolu } \\
\text { Sigorta }\end{array}$ & 0,162 & Bupa Acıbadem $(3,88)$ & 0 \\
\hline $\begin{array}{l}\text { Ankara } \\
\text { Sigorta }\end{array}$ & 0,613 & $\begin{array}{l}\text { Corpus (2,32), Bupa Acıbadem }(0,04) \text {, Chubb } \\
\qquad(0,07)\end{array}$ & 0 \\
\hline Axa & 0,349 & $\begin{array}{c}\text { Corpus }(6,07) \text {, Bupa Acıbadem }(0,63) \text {, Chubb } \\
(5,11)\end{array}$ & 0 \\
\hline Bereket & 0,324 & Demir Hayat $(0,88)$, Chubb $(0,08)$, Corpus $(2,42)$ & 0 \\
\hline $\begin{array}{l}\text { Bupa } \\
\text { Acıbadem }\end{array}$ & 1 & Bupa Acıbadem $(1,00)$ & 18 \\
\hline Chubb & 1 & Chubb $(1,00)$ & 17 \\
\hline Corpus & 1 & Corpus $(1,00)$ & 22 \\
\hline $\begin{array}{l}\text { Demir } \\
\text { Hayat }\end{array}$ & 1 & Demir Hayat $(1,00)$ & 8 \\
\hline $\begin{array}{l}\text { Doğa } \\
\text { Sigorta }\end{array}$ & 0,300 & $\begin{array}{l}\text { Chubb }(0,004) \text {, Corpus }(5,03) \text {, Bupa Acıbadem } \\
\qquad(0,14)\end{array}$ & 0 \\
\hline Dubai Starr & 0,966 & Corpus $(0,51)$, Demir Hayat $(0,20)$, Chubb $(0,46)$ & 0 \\
\hline Ethica & 0,796 & $\begin{array}{l}\text { Corpus }(0,85) \text {, Bupa Acıbadem }(0,01) \text {, Chubb } \\
\qquad(1,51)\end{array}$ & 0 \\
\hline Eureko & 0,088 & Bupa Acıbadem $(1,52)$ & 0 \\
\hline Generali & 0,397 & Demir Hayat $(1,32)$, Corpus $(0,97)$, Chubb $(0,69)$ & 0 \\
\hline Groupama & 0,247 & Corpus $(4,26)$, Bupa Acıbadem $(0,58)$ & 0 \\
\hline Gulf & 0,356 & Demir Hayat $(1,88)$, Corpus $(0,48)$, Chubb $(1,53)$ & 0 \\
\hline $\begin{array}{l}\text { Güneş } \\
\text { Sigorta }\end{array}$ & 0,105 & $\begin{array}{c}\text { Chubb }(0,77) \text {, Corpus }(3,46) \text {, Bupa Acibadem } \\
(1,28)\end{array}$ & 0 \\
\hline
\end{tabular}




\begin{tabular}{|c|c|c|c|}
\hline $\begin{array}{l}\text { Halk } \\
\text { Sigorta }\end{array}$ & 0,282 & $\begin{array}{c}\text { Chubb }(3,14) \text {, Corpus }(1,76) \text {, Bupa Acıbadem } \\
\qquad(0,11)\end{array}$ & 0 \\
\hline HDI & 0,128 & $\begin{array}{l}\text { Corpus }(5,65) \text {, Bupa Acıbadem }(0,10) \text {, Chubb } \\
\qquad(3,58)\end{array}$ & 0 \\
\hline Mapfre & 0,283 & Demir Hayat $(2,82)$, Corpus $(1,19)$ & 0 \\
\hline $\begin{array}{l}\text { Mapfre } \\
\text { Yaşam }\end{array}$ & 0,908 & BupaAcıbadem $(1,57)$ & 0 \\
\hline Neova & 0,184 & Corpus $(0,89)$, Demir Hayat $(0,21)$, Chubb $(0,03)$ & 0 \\
\hline Orient & 0,607 & Corpus $(5,48)$ & 0 \\
\hline Ray Sigorta & 0,109 & Corpus $(1,68)$ & 0 \\
\hline $\begin{array}{l}\text { Şeker } \\
\text { Sigorta }\end{array}$ & 0,668 & Demir Hayat $(0,19)$, Corpus $(3,22)$, & 0 \\
\hline $\begin{array}{l}\text { Sompo } \\
\text { Japan }\end{array}$ & 0,241 & Bupa Acıbadem $(0,28)$, Chubb $(0,58)$ & 0 \\
\hline $\begin{array}{l}\text { Türk } \\
\text { Nippon }\end{array}$ & 0,774 & Corpus $(1,49)$, Bupa Acıbadem $(0,01)$ & 0 \\
\hline Unico & 1 & $\begin{array}{l}\text { Corpus }(6,11) \text {, Bupa Acıbadem }(0,33) \text {, Chubb } \\
\qquad(5,95)\end{array}$ & 0 \\
\hline Ziraat & 1 & Corpus $(1,76)$, Bupa Acıbadem $(0,07)$ & 0 \\
\hline Zurich & 0,328 & Unico $(1,00)$ & 0 \\
\hline ORTALAMA & 0,520 & & \\
\hline
\end{tabular}

Referans grubunda Corpus, 22 defa referans olma frekansıyla etkin olmayan şirketler tarafından en çok referans alınan şirket konumundadır. Corpus'un ardından, Bupa Acıbadem 18, Chubb 17 ve Demir Hayat 8 defa referans alınma sayısına sahiptir. Etkin olmayan şirketlerin referans alması gereken şirketler ve oranları referans gruplarında verilmiştir. Örneğin, Aksigorta'nın etkin hale gelebilmesi için Corpus'u \%755, Bupa Acıbadem'i \%94 ve Chubb'ı \%58 oranında referans alması gerekmektedir.

\subsubsection{Yılı Analiz Sonuçları}

Tablo 5'te şirketlerin 2019 yılı etkinlik skorları referans grupları, referans olma ağırlıkları ve etkin şirketlerin referans olma sayıları verilmiştir. Buna göre, 2018 yılında etkin olan Bupa Acıbadem, Demir Hayat, Chubb, Corpus ve Ziraat; 2019'da da etkinlik skoruna ulaşmıştır. Dubai Starr ve Mapfre Yaşam ise ilk defa bu yıl etkin şirketler arasına katılmıştır. Bir önceki yılda etkin olan Unico ise bu yıl etkin şirketler arasında yer alamamıştır.

2017'de 0,482 ve 2018'de 0,520 olan genel etkinlik ortalaması 2019 yılında 0,541'e çıkarak 3 yıl boyunca sürekli yükselişini sürdürmüştür. Ayrıca 2017 yılında etkin şirket sayısı 5 iken 2018 yılında 6’ya, 2019'da ise 7'ye çıkmıştır. Bu sonuçlar 2017'den 2019'a kadar sigorta şirketlerinin sağlık/hastalık branşında etkinlik düzeylerinin genel olarak sürekli bir yükseliş trendi içinde seyrettiğini göstermektedir.

Tablo 5. 2019 Yılı Etkinlik Skorları ve Referans Grupları

\begin{tabular}{|c|c|c|c|}
\hline ŞirketAdı & $\begin{array}{l}2019 \\
\text { EtkinlikSkoru }\end{array}$ & $\begin{array}{c}\text { ReferansGrupları (Benchmarks) ve Lambda } \\
\text { Ağırlıkları (\%) }\end{array}$ & ReferansOImaSayısı \\
\hline Aksigorta & 0,237 & Dubai Starr $(1,09)$, Corpus $(4,72)$ & 0 \\
\hline Allianz & 0,568 & Bupa Acıbadem $(1,03)$, Chubb $(0,26)$ & 0 \\
\hline
\end{tabular}




\begin{tabular}{|c|c|c|c|}
\hline $\begin{array}{l}\text { Anadolu } \\
\text { Sigorta }\end{array}$ & 0,203 & $\begin{array}{l}\text { Corpus }(5,71) \text {, Bupa Acıbadem }(3,39) \text {, Chubb } \\
\qquad(2,88)\end{array}$ & 0 \\
\hline $\begin{array}{l}\text { Ankara } \\
\text { Sigorta }\end{array}$ & 0,811 & Bupa Acıbadem $(2,56)$ & 0 \\
\hline Axa & 0,253 & Chubb $(0,07)$, Dubai Starr $(1,09)$ & 0 \\
\hline Bereket & 0,386 & Bupa Acıbadem $(0,04)$, Corpus $(2,32)$ & 0 \\
\hline $\begin{array}{l}\text { Bupa } \\
\text { Acıbadem }\end{array}$ & 1 & $\begin{array}{l}\text { Corpus }(3,73) \text {, Bupa Acıbadem }(0,95) \text {, Chubb } \\
\qquad(3,95)\end{array}$ & 20 \\
\hline Chubb & 1 & $\begin{array}{l}\text { Corpus }(0,75) \text {, Demir Hayat }(0,69) \text {, Dubai Starr } \\
\qquad(1,19)\end{array}$ & 18 \\
\hline Corpus & 1 & Bupa Acıbadem $(1,00)$ & 20 \\
\hline $\begin{array}{l}\text { Demir } \\
\text { Hayat }\end{array}$ & 1 & Chubb $(1,00)$ & 5 \\
\hline $\begin{array}{l}\text { Doğa } \\
\text { Sigorta }\end{array}$ & 0,422 & Corpus $(1,00)$ & 0 \\
\hline Dubai Starr & 1 & Demir Hayat $(1,00)$ & 17 \\
\hline Ethica & 0,805 & Dubai Starr $(2,375)$ & 0 \\
\hline Eureko & 0,037 & $\begin{array}{c}\text { Bupa Acıbadem }(0,09) \text {, Corpus }(1,01), \text { Chubb } \\
(0,43)\end{array}$ & 0 \\
\hline Generali & 0,371 & Dubai Starr $(1,000)$ & 0 \\
\hline Groupama & 0,237 & $\begin{array}{l}\text { Corpus }(0,59) \text {, Chubb }(0,63) \text {, Bupa Acıbadem } \\
(0,01),\end{array}$ & 0 \\
\hline Gulf & 0,376 & Demir Hayat $(0,71)$, Bupa Acıbadem $(1,27)$ & 0 \\
\hline $\begin{array}{l}\text { Güneş } \\
\text { Sigorta }\end{array}$ & 0,243 & Dubai Starr $(2,41)$, Corpus $(0,13)$ & 0 \\
\hline $\begin{array}{l}\text { Halk } \\
\text { Sigorta }\end{array}$ & 0,284 & Bupa Acıbadem $(0,003)$, Chubb $(0,24)$ & 0 \\
\hline HDI & 0,153 & Dubai Starr $(0,53)$, Corpus $(2,52)$ & 0 \\
\hline Mapfre & 0,340 & Bupa Acıbadem $(0,54)$, Chubb $(0,44)$ & 0 \\
\hline $\begin{array}{l}\text { Mapfre } \\
\text { Yaşam }\end{array}$ & 1 & $\begin{array}{l}\text { Dubai Starr }(2,33) \text {, Chubb }(0,54) \text {, Bupa Acıbadem } \\
(0,03)\end{array}$ & 0 \\
\hline Neova & 0,235 & Dubai Starr $(1,98)$, Corpus $(1,54)$ & 0 \\
\hline Orient & 0,760 & Bupa Acıbadem $(0,72)$, Chubb $(2,93)$ & 0 \\
\hline Ray Sigorta & 0,172 & Chubb (1,83), Dubai Starr $(1,29)$ & 0 \\
\hline $\begin{array}{l}\text { Şeker } \\
\text { Sigorta }\end{array}$ & 0,694 & Bupa Acıbadem $(0,11)$, Corpus $(0,70)$ & 0 \\
\hline $\begin{array}{l}\text { Sompo } \\
\text { Japan }\end{array}$ & 0,163 & Dubai Starr $(1,11)$, Corpus $(5,06)$, & 0 \\
\hline $\begin{array}{l}\text { Türk } \\
\text { Nippon }\end{array}$ & 0,829 & Bupa Acıbadem $(0,20)$, Chubb $(1,61)$ & 0 \\
\hline Unico & 0,669 & $\begin{array}{c}\text { Demir Hayat }(2,85) \text {, Corpus }(1,002) \text {,Bupa } \\
\text { Acıbadem }(1,14)\end{array}$ & 0 \\
\hline Ziraat & 1 & Mapfre Yaşam $(1,00)$ & 0 \\
\hline Zurich & 0,522 & Chubb $(1,47)$, Dubai Starr $(1,89)$, Corpus $(0,97)$ & 0 \\
\hline ORTALAMA & 0,541 & & \\
\hline
\end{tabular}


Eureko 0,037 etkinlik skoruyla bu yıl da en düşük etkinlik düzeyine sahip şirket olmuştur. Eureko'nun ardından HDI $(0,153)$ ve Sompo Japan $(0,163)$ en az etkin olan ikinci ve üçüncü şirketlerdir. Etkin olmayan şirketler arasında Türk Nippon 0,829 ve Ankara Sigorta 0,811 etkinlik skorlarıla etkin olmaya en çok yaklaşan şirketlerdir.

Referans grubunda Corpus ile Bupa Acıbadem 20'şer defa referans olma frekansıyla etkin olmayan şirketler tarafından en çok referans alınan şirketler olmuştur. Onları Chubb (18), Dubai Starr(17) ve Demir Hayat (5) takip etmiştir. Etkin olmayan şirketlerin referans alması gereken şirketler ve oranları referans gruplarında verilmiştir. Örneğin, Allianz'ın etkin hale gelebilmesi için Corpus'u \%571, Bupa Acıbadem'i \%339 ve Chubb'ı \%288 oranında referans alması gerekmektedir.

\subsection{Analiz Sonuçlarının Değerlendirilmesi ve Yorumlanması}

Tablo 6. Şirketlerin Yıllara Göre CCR ve BCC Çıktı Yönlü Etkinlik Skorları

\begin{tabular}{|c|c|c|c|c|c|c|}
\hline ŞirketAdı & 2017 CCR & 2017 BCC & 2018 CCR & 2018 BCC & 2019 CCR & 2019 BCC \\
\hline Aksigorta & 0,241 & 0,579 & 0,256 & 0,617 & 0,237 & 0,627 \\
\hline Allianz & 0,625 & 1 & 0,652 & 1 & 0,568 & 1 \\
\hline Anadolu Sigorta & 0,148 & 0,393 & 0,162 & 0,408 & 0,203 & 0,367 \\
\hline Ankara Sigorta & 0,756 & 1 & 0,613 & 0,907 & 0,811 & 1 \\
\hline Axa & 0,228 & 0,430 & 0,349 & 0,693 & 0,253 & 0,649 \\
\hline Bereket & 0,333 & 0,528 & 0,324 & 0,759 & 0,386 & 0,753 \\
\hline Bupa Acıbadem & 1 & 1 & 1 & 1 & 1 & 1 \\
\hline Chubb & 1 & 1 & 1 & 1 & 1 & 1 \\
\hline Corpus & 1 & 1 & 1 & 1 & 1 & 1 \\
\hline Demir Hayat & 1 & 1 & 1 & 1 & 1 & 1 \\
\hline Doğa Sigorta & 0,223 & 0,381 & 0,300 & 0,651 & 0,422 & 0,896 \\
\hline Dubai Starr & 0,766 & 0,809 & 0,966 & 1 & 1 & 1 \\
\hline Ethica & 0,751 & 0,857 & 0,796 & 0,931 & 0,805 & 0,927 \\
\hline Eureko & 0,094 & 0,136 & 0,088 & 0,130 & 0,037 & 0,047 \\
\hline Generali & 0,311 & 0,537 & 0,397 & 0,626 & 0,371 & 0,678 \\
\hline Groupama & 0,249 & 0,463 & 0,247 & 0,375 & 0,237 & 0,457 \\
\hline Gulf & 0,393 & 0,484 & 0,356 & 0,535 & 0,376 & 0,642 \\
\hline Güneş Sigorta & 0,081 & 0,134 & 0,105 & 0,152 & 0,243 & 0,482 \\
\hline Halk Sigorta & 0,289 & 0,432 & 0,282 & 0,494 & 0,284 & 0,544 \\
\hline $\mathrm{HDI}$ & 0,173 & 0,297 & 0,128 & 0,278 & 0,153 & 0,413 \\
\hline Mapfre & 0,204 & 0,411 & 0,283 & 0,488 & 0,340 & 0,725 \\
\hline Mapfre Yaşam & 0,838 & 0,872 & 0,908 & 0,969 & 1 & 1 \\
\hline Neova & 0,204 & 0,341 & 0,184 & 0,369 & 0,235 & 0,482 \\
\hline Orient & 0,598 & 0,889 & 0,607 & 0,897 & 0,760 & 0,890 \\
\hline Ray Sigorta & 0,185 & 0,343 & 0,109 & 0,212 & 0,172 & 0,400 \\
\hline Şeker Sigorta & 0,685 & 0,785 & 0,668 & 0,821 & 0,694 & 0,868 \\
\hline Sompo Japan & 0,225 & 0,585 & 0,241 & 0,720 & 0,163 & 0,470 \\
\hline Türk Nippon & 0,739 & 0,900 & 0,774 & 1 & 0,829 & 0,978 \\
\hline Unico & 0,307 & 0,656 & 1 & 1 & 0,669 & 1 \\
\hline Ziraat & 1 & 1 & 1 & 1 & 1 & 1 \\
\hline Zurich & 0,308 & 0,341 & 0,328 & 0,369 & 0,522 & 0,596 \\
\hline ORTALAMA & 0,482 & 0,632 & 0,520 & 0,691 & 0,541 & 0,738 \\
\hline Etkin Şirket Sayısı & 5 & 7 & 6 & 9 & 7 & 10 \\
\hline
\end{tabular}


Tablo 6'da görüldüğü gibi, şirketlerin BCC modeldeki etkinlik skorları CCR modele göre daha yüksek gerçekleşmiştir. Örneğin 2019'da CCR modelde 7 şirket etkin durumdayken BCC'de etkin olan şirketlerin sayısı 10'dur. Bu durumun en önemli sebebi, Veri Zarflama Analizi'nde BCC modelde CCR modele göre etkinlik skorlarının daha yüksek gerçekleşiyor olmasıdır. Diğer bir deyişle, BCC modelinin daha esnek yapıda olması ve ölçeğe göre değişken getiri varsayımını kullanması bu modeldeki etkinlik düzeylerini arttırmaktadır.

Ölçeğe göre değişken getiri varsayımı (VRS) çerçevesinde etkinlik analizi yapan BCC model, teknik etkinliği; ölçeğe göre sabit getiri varsayımı (CRS) çerçevesinde etkinlik analizi yapan CCR model ise toplam etkinliği açıklamaktadır. Toplam etkinlik, teknik etkinliği ve ölçek etkinliğini kapsadığından dolayı BCC modelde etkin olan bazı birimler CCR modelde etkinlik düzeyine ulaşamamıştır. Örneğin 2019 yılında BCC modelde etkinlik skoru 1 olan Allianz'ın, aynı yıl CCR modeldeki etkinlik skoru 0,568'de kalmış ve şirket etkin olamamıştır. Tabloda görüldüğü gibi, bazı sigorta şirketleri teknik olarak etkin durumda olsalar bile ölçek etkinliğine sahip olmadıklarından dolayı CCR model toplam etkinlik skorları 1'in altında kalmıştır.

İnsan ve hizmet odaklı sigortacılık sektöründe faaliyet gösteren sigorta şirketlerinin mali açıdan etkin olması hem söz konusu şirketlerin kendisi hem de hizmet sundukları sigortalıları açısından büyük önem taşımaktadır. Sigortacılık sektörü sermaye piyasalarına fon sağladığından dolayı, sigorta şirketlerinin finansal açıdan etkin olması dolaylı olarak ülke ekonomisini de etkilemektedir. Etkin olan sigorta şirketleri, etkin olmayanlara göre daha az maliyetle hizmet sağlamakta ve böylece göreli olarak önemli bir maliyet avantajı yakalamaktadır. Etkin şekilde hizmet üretemeyen şirketlerin maliyetlerinin daha yüksek olması, sektörde uzun süre faaliyet göstermelerini zorlaştırmaktadır. Bu sebeple etkin olmayan şirketlerin belirli girdi bileşimiyle sundukları hizmet çıktılarını gelecek dönemlerde mutlaka arttırması gerekmektedir.

Şirketlerin etkinliğinin en önemli göstergesi, sunulan hizmetlerin kalitesinde herhangi bir düşüş olmadan kaynakların etkin şekilde kullanılmasını sağlamaktır. Kaynakların etkin kullanılması, üretim ve finans sektöründe olduğu gibi sigortacılıkta da karlılığın artmasını sağlamakta ve mali sürdürülebilirliği desteklemektedir. Bu şekilde daha az işgücü ve enerji ile daha kaliteli ve daha fazla miktarda hizmetin sunulması mümkün olmaktadır. Şirketler, etkinlik durumlarını ölçerek finansal sürdürülebilirliklerini ve performans göstergelerini analiz edebilmektedir.

Sigortacılık sektöründe hastalık/sağlık branşının ve özel sağlık sigortasının son derece özel ve önemli bir yeri bulunmaktadır. Sağlık hizmetleri ve sağlık ihtiyacı, talep edenler açısından ikamesi ve çoğu zaman ertelenmesi mümkün olmayan bir hizmet çeşididir. Son yıllarda sağlık teknolojisinin sürekli gelişmesi, toplumun sağlık konusunda daha bilinçli hale gelmesi ve bireylerin kaliteli ve yüksek standartlarda sağlık hizmeti temin etme arzusu sağlık sistemlerinin, sağlık finansmanının ve özellikle de özel sağlık sigortacılı̆̆ının arz ettiği önemi bir kat daha arttırmıştır. Özellikle tüm Dünyayı etkisi altına alan Covid 19 Pandemisinin meydana gelmesiyle birlikte, özel sağlık sigortalarının popülerliği artmış ve bu sigortalara olan talep adeta patlama yapmıştır.

\section{Sonuç}

Literatür taraması ve Veri Zarflama Analizi uygulanarak hazırlanan bu çalışmada Türkiye'de faaliyet gösteren 31 sigorta şirketinin 2017, 2018 ve 2019 yıllarında sağlık/hastalık branşı etkinlik analizi gerçekleştirilmiştir. Bu analiz neticesinde, özel sağıık sigortalarının etkinlik düzeylerini arttırmayı hedefleyen öneriler ileri sürülmüştür.

Çalışmada CCR ve BBC model çıktıya yönelik etkinlik ölçümü yapılmıştır. CCR modelde 2017 yılında toplam 5, 2018'de 6 ve 2019'da ise 7 şirket etkindir. Etkinlik ortalamalarının nispeten daha yüksek olduğu teknik etkinliği ölçen BCC modelde ise etkin olan şirket sayısı 2018'de 9, 2017'de 7 ve 2019'da ise $10^{\prime}$ dur. CCR'da etkinlik ortalamalarının 0,482 ile 0,541 aralığında olduğu görülürken, BCC'de ise 0,632 ile 
0,738 arasında değiş̧mektedir. Ayrıca 2017 yılından 2019 yılına kadar, hem CCR'da hem de BCC'de etkinlik ortalamalarının ve etkin şirket sayısının sürekli yükseldiği göze çarpmaktadır.

Araştırmada elde edilen buğular doğrultusunda söz konusu şirketlerinin toplam etkinliğinin analizin yapıldığı 3 yıl içerisinde sürekli yükseliş seyri gösterdiği saptanmıştır. Çalışmada ulaşılan verilerin ve bulguların, söz konusu hususlarda bilgi edinmek isteyen sigorta şirketlerinin yönetici veya ortaklarına fayda ve katkı sağlayacağı umulmaktadır. Sigorta şirketleri bu ve benzeri çalışmalardaki analiz ve ölçümler sayesinde güçlü ve zayıf yönlerini, mali açıdan yeterli ve yetersiz olduğu noktaları tespit edebilmekte; ayrıca fazla kullandıkları girdileri ve yetersiz çıktıları hakkında bilgi ve fikir sahibi olabilmektedir. Böylece, kaynakların israf edilmesi minimize edilerek ve yönetsel stratejiler geliştirilerek sınırlı kaynakların optimal düzeyde kullanılması sağlanabilmektedir.

Özel sağlık sigortalarının etkinlik düzeylerinin arttırılması için öncelikle sigortalı sayısının artması gerekmektedir. Özel sağlık sigortası yaptıran kişi sayısı çoğaldıkça sigorta şirketlerinin prim üretimleri ve teknik kar çıktıları da buna paralel olarak artış gösterecektir. Bu artışlar, şirketlerin etkinlik durumuna olumlu yansımaktadır. Sigorta şirketlerinin orta ve uzun vadede varlıklarını devam ettirmeleri ve sürdürülebilir yapıda olmaları finansal açıdan etkin şekilde faaliyet yürütmelerine bağlıdır. Çalışmada bu sebeple sigorta şirketlerinin etkinlik düzeylerini ölçmek amacıyla Veri Zarflama Yöntemi kullanılarak etkinlik analizi yapılmıştır.

Özel sağıı sigortası şirketlerinin etkinlik düzeylerini arttırmak amacıyla çeşitli faaliyet ve uygulamaları hayata geçirmesi gerekmektedir:

Sigorta şirketlerinin prim üretimi, sigortalı sayısı ve teknik kar unsurlarını arttırabilmesi için tanıtım ve bilinirlik arttırıcı faaliyetlerini geliştirmesi ve yaygınlaştırması büyük önem taşımaktadır. Türkiye toplumunda sigortanın gerekliliği ve önemi konusunda yeterince bilgi ve farkındalık gelişmemiş durumdadır. Genellikle bireyler herhangi bir sağlık sorunu veya hastalık yaşamadığı sürece sigorta yaptırma gereği ve isteği duymamaktadır. Birçok Avrupa ülkesine kıyasla Türkiye'de sigorta bilinci halk nezdinde yeterince yerleşmemiştir. Toplumun bazı kesimlerince sigorta, bir ihtiyaç ve gereklilikten ziyade lüks olarak görülmektedir. Keskin (2019) tarafından özel sağlık sigortalarının gelişme potansiyeli üzerine tüketici görüşlerinin belirlenmesi amacıyla yapılan anket çalışmasında katılımcıların büyük çoğunluğu özel sağlık sigortaları hakkında yeterli bilgiye sahip olmadığını ileri sürmüş ve özel sağlık sigortası hakkında daha fazla bilgiye sahip olmak istediklerini belirtmiştir. Bu sebeplerle sigorta şirketleri topluma ve özellikle müşteri kitlesine kendilerini iyi tanıtmalı, gerekli reklam, pazarlama, tanıtım ve PR faaliyetlerine önem vermelidir. Bu doğrultuda şirketler dağıtım kanallarını, acente faaliyetlerini ve satış kadrosunu güçlendirmelidir. Şirketlerin satış ve pazarlama kadrosunda ikna kabiliyeti yüksek, alanında iyi eğitimli ve sigorta işlemlerini topluma doğru tanıtabilen profesyonel personeller istihdam edilmelidir. Sigorta şirketleri normal şartlarda mevcut girdileriyle daha fazla prim üretebilecek potansiyele sahiptir. Bu bakımdan, sigortalılarla birebir temas kuran acente personelinin potansiyel sigortalılarla kurdukları iletişimde dürüst, şeffaf ve güvenilir olması büyük önem taşımaktadır. Ayrıca sigorta acenteleri söz konusu reklam ve tanıtım faaliyetlerini özellikle genç kitlelerin daha aktif ve yoğun olduğu sosyal medya platformlarında da tatbik etmelidir.

Sigortalı sayısı ve buna paralel olarak prim üretimlerinin arttırılabilmesi için bireylerin şahsi ihtiyaç ve talepleri doğrultusunda kişiye özgü ürünler ve cazip promosyonlar hazırlanmalıdır. Hollanda, Birleşik Krallık ve Almanya'da sigortalıların kendi ihtiyaç ve taleplerine yönelik geniş veya dar kapsamlı bireysel poliçeler düzenlenmektedir. Türkiye'de de benzer şekilde, bireylerin kendi ihtiyaç ve taleplerine hitap edecek şekilde poliçelerin kişiye özgü çeşitlendirilmesi ve özelleştirilmesi özel sağlık sigortacılığının gelişimini hızlandıracaktır. Özellikle diş tedavileri, gözlük cam ve çerçeve masrafları ve sağlığa yardımcı çeşitli malzemeler gibi tıbbi mal ve hizmetlerin yer aldığı kişiye özel teminatları içeren poliçeler müşteri memnuniyetini arttırmaktadır. Bu amaçla özel sağıık sigortası yaptırmayı düşünen kişilerin talep ve 
eğilimleri iyi analiz edilerek ve ürün çeşitlendirmesi yapılarak kişiye özgü zenginleştirilmiş teminatlı poliçeler sunulmalıdır. Bireysel ihtiyaçlara hitap eden ve şirketler için karlılı̆ı yüksek olan sigorta ürünlerinin satılmasıyla prim üretimlerini artması muhtemeldir.

Türkiye'de toplumun bazı kesimlerinde sigortaya ve sigorta şirketlerine güvensizlik ve şüphe duygusu oluşabilmektedir. Özellikle sağlık sigortalarında bazı sigortalılar, sigorta şirketlerinin hasarı ödememek için çeşitli şartlar koyduğunu öne sürmektedir. Ayrıca sağlık sigortası şirketlerinin aynı ürün ve teminatlar için farklı fiyatlar talep etmesi sigorta yaptırmak isteyen kişilerde özel sağlık sigortasına karşı tereddüt ve güvensizlik duygusu oluşturabilmektedir. Bu güvensizlik algısının ve olumsuz imajın ortadan kaldırılması için sigorta şirketleri daha net ve şeffaf şekilde çalışmalarını sürdürmelidir. Bu amaçla şirketler kendilerini iyi ifade etmeli ve potansiyel müşterilerinin güvenini kazanmaya çalışmalıdır. Fiyatlandırmadaki farklılıklar minimize edilmeli ve sağlık sigortası poliçelerinin faturalandırılmasında teminatlara göre belirli bir standardizasyon getirilmelidir.

Sigorta sektörü, yapısı gereği ekonomik göstergelerdeki değişimlerden çok çabuk etkilenmektedir. Ekonomide bozulmaların yaşandığı dönemlerde sigorta şirketlerinin etkinlik düzeylerinde düşüşler yaşanmaktadır. Refah düzeyi yüksek ülkelerle karşılaştırıldığında, Türkiye'de sigorta sektörünün yeterince gelişememesinin en önemli sebebi ülkedeki ekonomik faktörlerdir. Gelir dağılımındaki adaletsizlikler, sürekli artan döviz kurları, milli para biriminin değer kaybetmesi, enflasyonun yüksek seyretmesi ve söz konusu ekonomik istikrarsızlıklar sigorta sektörünü ve sağlık sigortacılığının gelişimini olumsuz etkilemektedir. Mevcut ekonomik koşullarda alım gücü düşen bireyler sağlık sigortası satın almakta güçlük çekmektedir. Enflasyonun yükselmesi, özellikle sağlık ve hayat sigortalarında sonraki yılların prim tutarlarını arttırmaktadır. Bunun sonucunda da sigortaya olan talep azalmaktadır.

Sigortacılık sektörünün ve özelde özel sağlık sigortacılığının gelişmesi ve büyümesi öncelikli olarak makro ve mikro düzeyde ekonomik şartların iyileştirilmesine bağlıdır. Bu bakımdan işsizlik ve enflasyon oranlarının düşürülmesi, gelir düzeyinin arttırılması, gelir dağılımındaki adaletsizliklerin giderilmesi ve toplumun genel refah seviyesinin yükseltilmesi gerekmektedir. Bu amaçla, siyasi otoritenin ve yetkili kamu organlarının doğru ekonomi politikalarını ve faaliyetlerini hayata geçirmesi sektörün gelişimi açısından büyük önem arz etmektedir. Sigorta şirketlerinin etkinliklerinin yükselmesi büyük oranda ekonomik göstergelerin olumlu seyretmesine bağlıdır.

Özel sağlık sigortalarının ekonomideki söz konusu katkı ve avantajlarının gerçekleşebilmesi için öncelikli olarak sigorta şirketlerinin finansal açıdan etkin faaliyet göstermesi gereklidir. Şirketlerin etkin olması, en az maliyetle ve mevcut kaynaklarla maksimum çıktı üretebilme kapasitesini ifade etmektedir. Etkin durumda olmayan şirketlerin mali sürdürülebilirliği tehlikeye girmektedir. Özel sağlık sigortacılığının etkin çalışması sermayenin verimliliğini arttırmakta ve böylece ülke çapındaki tasarrufların yatırımlara ayrılan kısmını yükselterek ekonomik büyümeye katkı sağlamaktadır. Çalışmada bahsi geçen görüş ve önerilerin özel sağlık sigortası şirketlerinin etkinliğini arttırmaya katkı sağlayacağı umulmaktadır

Hakem Değerlendirmesi: Dış bağımsız.

Çıkar Çatışması: Yazar çıkar çatışması bildirmemiştir.

Finansal Destek: Yazar bu çalışma için finansal destek almadığın beyan etmiştir.

\section{Kaynakça}

Adler, N., Friedman, L. \&Snuany-Stern, Z. (2002). Review of Ranking Methods in the Data Envelopement Analysis Context. European Journal of Operational Research, 140(2), 249-265. 
Afonso, A. \& Aubyn, M. (2011). Assessing health efficiency across countries with a two-step and bootsrap analysis. Taylor \& Francis Journals, 18(15), 1427-1430.

Asandului, L., Roman, M. \& Fatulescu, P. (2014). The efficiency of health care systems in europe: a data envelopment analysis approach. Procedia Economic sand Finance, 10(1), 261-268.

Bakırcı, F. (2006). Üretimde etkinlik ve verimlilik ölçümü (1. bs.). Ankara: Nobel Akademik Yayıncılık.

Banker, R.D., Charnes, A. \& Cooper, W.W. (1984). Some models for estimating technical and scale inefficiencies in Data Envelopment Analysis. Management Science, 30(9), 1078-1092.

Banker, R. D. \&Thrall, R. M. (1992). Estimation of returns to scale using Data Envlopement Analysis. European Journal of Operational Research, 62(1), 74-84.

Bölükbaşı, A. ve Pamukçu, B. (2008). Sigortacılıkta risk yönetimi (1. bs.). İstanbul: Türkmen Kitabevi.

Civan, A. (2010). Türkiye'de sağlık sigortacılığı sistemi. İstanbul: Umut Matbaacılık,

Claxton, G. (2002). How private insurance works: A primer. Washington: Georgetown University Press.

Charnes, A., Cooper, W. W., Lewin, A. Y. \& Seiford, L.M. (1994). Data Envelopement Analysis: Theory, methodology and applications. Boston: Kluwer Academic Publishers.

Cooper, W.W., Seiford, L. ve Tone, K. (2000). Data Envelopement Analysis: A comprehensive text with models, applications, references and DEA solve rsoftware. New York: Kluwer Academic Publishers,

Cooper, W.W., Seiford, L. M. \& Zhu, J. (2011). Data Envelopement Analysis: History, models and interpretations. Berlin: Springer Science + Business Media.

Coelli, T. (1998). A multi-stage methodology for the solution of orientated DEA models. Operations Research Letters, 23(3), 143-149.

Çakmak, M., Öktem, M. K. ve Ömürgönülşen, U. (2009). Türk kamu hastanelerinde teknik verimlilik sorunu: Veri Zarflama Analizi Tekniği ile Sağlık Bakanlığı'na bağlı kadın doğum hastanelerinin teknik verimliliklerinin ölçülmesi. Hacettepe Sağlık Idaresi Dergisi, 12(1), 1-36.

Çelik, Y. (2016). Sağlık ekonomisi. Ankara: Siyasal Yayın Dağıtım.

Dinçer, E.(2008). Veri Zarflama Analizi'nde Malmquist endeksiyle toplam faktör verimliliği değişiminin incelenmesi ve IMKB üzerine bir uygulama. Marmara Üniversitesi iktisadi ve Idari Bilimler Dergisi, 25(2), 825-846.

Dizdar, T. (Kasım 2014). Tamamlayıcı sağlık sigortası. OHSADErişim Adresi: http://sasder.org/Content/DOCS/Sunumlar/3/Tamamlayici-Saglik-Sigortasi_TDizdar.pdf.

Doğukan, M. N. Özel sağlık sigortası. Sosyal Güvenlik KurumuErişim Adresi: http://sasder.org/Content/DOCS/Sunumlar/3/Tamamlayici-Saglik-Sigortasi_MNurdanDogukan.pdf.

Drechsler, D. \& Jutting, P.J. (2005). Private health insurance for the poor in developing countries?. Policy Insights, 11(2), 1-7.

Erkek, N. ve Erkek, F. (2012). Tamamlayıcı sağlık sigortası ve Türkiye. Sosyal Güvenlik Dünyası Dergisi, (79), 24-43.

Ertuğrul, ì. ve Işık, A. (2008). İşletmelerin VZA ile mali tablolarına dayalı etkinlik ölçümü: Metal ana sanayiinde bir uygulama. Afyon Kocatepe Üniversitesi i.I.B.F. Dergisi, 10(1), 201-217. 
Gottret, P. \&Schiber, G. (2006). Health financing revisited-A practitioner's guide. Washington D.C.: The World Bank.

Karsak, E. E. ve İşcan, F. (2000). Çimento sektöründe göreli faaliyet performanslarının ağırlık kısıtlamaları ve çapraz etkinlik kullanılarak Veri Zarflama Analizi ile değerlendirilmesi. Endüstri Mühendisliği Dergisi, 11(3), 2-10.

Kaya, F. ve Kahya, M. (2017). Sigorta ve sigortacılık (1. bs). Ankara: Beta Yayıncılık.

Keskin, H. Özel sağlık sigortasının gelişme potansiyeli üzerine tüketici görüşlerinin belirlenmesi: Ankara ili örneği. (Yayınlanmış yüksek lisans tezi). Gazi Üniversitesi Sosyal Bilimler Enstitüsü, Ankara.

Kılınç, F. E. (2009). Türk sigortacılık sektörünün Veri Zarflama Analizi yöntemi ile etkinliğinin araştırılması. (Yayınlanmış yüksek lisans tezi). Süleyman Demirel Üniversitesi Sosyal Bilimler Enstitüsü, Isparta.

Lister, J. (2008). Sağıık politikası reformu: Yanlış yolda mı gidiyoruz?. İstanbul: İnsev Yayınları.

Lorcu, F. (2008). Veri Zarflama Analizi ile Türkiye ve Avrupa Birliği ülkelerinin sağlık alanındaki etkinliklerinin değerlendirilmesi. (Yayınlanmamış doktora tezi). İstanbul Üniversitesi Sosyal Bilimler Enstitüsü, İstanbul.

Medeiros, J. \&Schwierz, C. (2015). Efficiency estimates of healthcare systems in the EU. Brussels: European Commission.

Mirmirani, S. (2008). Healthcare efficiency in transition economies: An application of Data Envelopment Analysis. International Business \&Economics Research Journal, 7(2), 47-56

Mirmirani, S. \& Lippman, M. (2003). Healthcare system efficiency analysis of G12 countries. International Business and Economics ResearchJ ournal, 3(5), 35-42.

Mossialos, E. \&Thomson, S. (2004). Voluntary health insurance in the European Union. Brussels: European Observatory on Health Systems and Policies.

OECD, (June 2004). Proposal for a taxonomy of health insurance. Erişim Adresi:https://www.oecd.org/health/health-systems/31916207.pdf.

OECD (2019), OECD Health statistics 2019: Definitions, resources and methods - Private health insurance. Erişim Adresi:http://stats.oecd.org/wbos/fileview2.aspx?IDFile=e11b92da-6cc5-4cea-afe91d4cce02e5a4.

Özer, Ö., Gözlü, M., Karsavuran, S. Ve Gözlü, K. (2014). Türkiye sağlık finansmanında yeni bir alternatif: Tamamlayıcı sağlık sigortası. Akademik Bakış Dergisi, (42), 10-11.

Orhaner, E. (2006). Türkiye'de sağlık hizmetleri finansmanı ve Genel Sağlık Sigortası. Ticaret ve Turizm Eğitim Fakültesi Dergisi, 1(1), 22-41.

Orhaner, E. ve Ekinci, N. (2019). Ankara'da yaşayan kişilerin özel sağlık sigortalarına ilişkin görüşlerinin değerlendirilmesi. Sağlık Akademisyenleri Dergisi, 6(1), 34-42.

Özbolat, M. (2014). Temel sigortacılık (6. bs). Ankara: Seçkin Yayıncılık.

Su, M. (2004). Özel sağlık sigortası sistemine giren kişilerin sayısında önemli düşüş olacaktır. Türkiye işveren Sendikaları Konfederasyonu Dergisi, 2(1), 1-23.

Tajika, E. ve Kikuchi, J. (2012), The Roles of Public and Private Insurance for the healthcare Reform of Japan. Policy Research Institute, 8(2), 125-137.

Tarım, A. (2001). Veri Zarflama Analizi: Matematiksel programlama tabanlı göreli etkinlik ölçüm yaklaşımı: inceleme (1. bs.). Ankara: T.C. Sayıştay Başkanlığı. 
T.C. Hazine ve Maliye Bakanlığı Sigorta Denetleme Kurulu. (2019). Sigortacılık ve Bireysel Emeklilik Faaliyetleri Hakkında Rapor 2018. Ankara.

T.C. Hazine ve Maliye Bakanlığı Sigorta Denetleme Kurulu. (2020). Sigortacılık ve Bireysel Emeklilik Faaliyetleri Hakkında Rapor 2019. Ankara.

Tetik, S. (2003). İşletme performansını belirlemede Veri Zarflama Analizi. Yönetim ve Ekonomi, 10(2), 221229.

Türkiye Sigorta Birliği. (2021). Resmi İstatistikler, Sağılık Analizleri 2010 - 2020. Erişim Adresi:https://www.tsb.org.tr/resmi-istatistikler.aspx?pageID=909.

Tütek, H., Gümüşoğlu, Ş. ve Özdemir, A. (2012). Sayısal yöntemler yönetsel yaklaşım. (6. bs.). İstanbul: Beta Basım Yayın.

Yıldız, U. (2012). Özel sağıık sigortacılığı sektöründe faaliyet gösteren şirketlerin Veri Zarflama Analizi ile etkinliğinin ölçülmesi. (Yayınlanmamış Yüksek Lisans Tezi). Gaziosmanpaşa Üniversitesi Sosyal Bilimler Enstitüsü, Tokat.

Yolalan, R. (1993). İşletmeler arası göreli etkinlik ölçümü (1. bs.). Ankara: Milli Prodüktivite Merkezi Yayınları. 